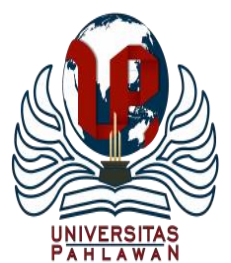

Edukatif : Jurnal Ilmu Pendidikan Volume 3 Nomor 5 Tahun 2021 Halm 2194 - 2199 EDUKATIF: JURNAL ILMU PENDIDIKAN

Research \& Learning in Education

https://edukatif.org/index.php/edukatif/index

\title{
Praktikalitas dan Efektivitas Pengembangan Mobile Learning Berbasis Moodle pada Mata Pelajaran Pengetahuan Bahan Makanan di Sekolah Menengah Kejuruan
}

\author{
Anni Faridah ${ }^{1}{ }^{凶}$, Titen Darlis Santi ${ }^{2}$ \\ Universitas Negeri Padang, Indonesia ${ }^{1,2}$ \\ E-mail : faridah.anni@fpp.unp.ac.id ${ }^{1}, \underline{\text { titendarlissanti77@ @mail.com }}^{2}$
}

\begin{abstract}
Abstrak
Mobile Learning untuk proses belajaran dibutuhkan pada saat sekarang, karena di Era Revolusi Industri 4.0 agar arah perkembangan ilmu pengetahuan dan teknologi dapat menuju sasaran yang tepat yaitu dunia pendidikan, karena masih banyak guru-guru yang terkendala dalam menggunakan media pembelajaran yang praktis dan efektif dalam proses belajar mengajar. Pemanfaatan media pembelajaran di SMK Pariwisata Aisyiyah masih dominan menggunakan buku cetak sehingga kurang praktis dan efektif untuk mengikuti perkembangan teknologi sekarang, maka pengembangan media Mobile Learning berbasis Moodle sangat perlu dalam proses pembelajaran. Tujuan penelitian adalah Praktikalitas dan efektifitas Mobile Learning berbasis Moodle pada mata Pelajaran Pengetahuan Bahan Makanan di Sekolah Menengah Kejuruan. Metode Penelitian dan Pengembangan yaitu $R \& D$ for education, dengan menggunakan model pengembangan Four-D. Hasil penelitiannya yaitu untuk praktikalitas diperoleh dari 2 aspek yaitu guru dengan rata-rata 95,6\% kategori "Sangat Praktis" dan siswa diperoleh rata-rata 94\% dengan kategori "Sangat Praktis" selanjutnya untuk efektifitas media pembelajaran dinyatakan sangat efektif karena bisa meningkatkan hasil belajar siswa yang dinyatakan dengan nilai siswa yang berada di atas KKM.sehingga media Mobile Learning ini mampu meningkatkan pengetahuan, motivasi belajar, berfikir kritis, belajar mandiri, keaktifan dan keefektifan pembelajaran.
\end{abstract}

Kata Kunci: Media, M-Learning, Moodle, Praktikalitas, Efektifitas.

\begin{abstract}
Mobile Learning for the learning process is needed at this time, because in the Industrial Revolution Era 4.0 so that the direction of the development of science and technology can lead to the right target, namely the world of education because there are still many teachers who are constrained in using practical and effective learning media in the learning process. learn how to teach. The use of learning media in Aisyiyah Tourism Vocational School is still dominantly using printed books so that it is less practical and effective to keep up with current technological developments, so the development of Moodle-based Mobile Learning media is very necessary for the learning process. The purpose of this research is the practicality and effectiveness of Moodle-based Mobile Learning in Food Materials Knowledge subjects in Vocational High Schools. The research and development method is $R \& D$ for education, using the Four-D development model. The results of the research are for practicality obtained from 2 aspects, namely teachers with an average of 95.6\% in the "Very Practical" category and students obtained an average of 94\% in the "Very Practical" category. student learning which is stated by the value of students who are above the KKM. So this Mobile Learning media can increase knowledge, learning motivation, critical thinking, independent learning, activeness, and effectiveness of learning.
\end{abstract}

Keywords: Media, M-Learning, Moodle, Practicality, Effectiveness.

Copyright (c) 2021 Anni Faridah, Titen Darlis Santi

$\triangle$ Corresponding author

Email : faridah.anni@fpp.unp.ac.id

DOI $\quad$ : https://doi.org/10.31004/edukatif.v3i5.763

ISSN 2656-8063 (Media Cetak)

ISSN 2656-8071 (Media Online)

Edukatif : Jurnal Ilmu Pendidikan Vol 3 No 5 Tahun 2021 p-ISSN 2656-8063 e-ISSN 2656-8071 
2195 Praktikalitas dan Efektivitas Pengembangan Mobile Learning Berbasis Moodle pada Mata Pelajaran Pengetahuan Bahan Makanan di Sekolah Menengah Kejuruan - Anni Faridah, Titen Darlis Santi

DOI: https://doi.org/10.31004/edukatif.v3i5.763

\section{PENDAHULUAN}

Media pembelajaran yang dibutuhkan oleh dunia pendidikan sekarang adalah yang praktis dan efektif digunakan dalam proses pembelajaran, salah satunya dengan memanfaatkan Mobile Learning. Hal ini sesuai pendapat (Rahman, D. N. A., Saputra, D. S., \& Kurino, 2019), pembelajaran berbasis mobile learning merupakan pembelajaran yang terbilang praktis, dan simpel karena pembelajarannya tidak terpaku oleh waktu dan tempat.

Mobile learning yang dikembangkan bisa dalam bentuk bahan ajar atau berupa Aplikasi (apk), web yang bisa di akses dan dimanfaatkan siswa dalam pembelajaran, sehingga pembelajaran bisa lebih menarik dan praktis, baik untuk guru maupun siswa. Disini media yang dikembangkan yaitu Mobile Learning berbasis Moodle, karena moodle adalah aplikasi belajar mengajarkan yang memanfaatkan teknologi informasi berbasis web, atau sering disebut E-Learning. Moodle salah satu Learning Management System populer dan open source yang dikembangkan untuk pembelajaran ke dalam bentuk website dan dapat diakses menggunakan perangkat smartphone melalui aplikasi, dengan kelebihan utama membangun proses pembelajaran yang menarik, interaktif, praktis, dan efisien. Media pembelajaran Mobile Learning dibutuhkan pada era revolusi 4.0.

Pendidikan di era revolusi industri 4.0 menjelaskan tentang bagaimana cara menggabungkan teknologi cyber secara fisik dan Teknologi Informasi dan Komunikasi (TIK) yang sangat pesat, harus selaras dengan peningkatan mutu sumber daya manusia agar arah perkembangan ilmu pengetahuan dan teknologi dapat menuju sasaran yang tepat (Rohida, 2018) pendidikan revolusi industri 4.0 merupakan kejadian yang menggambarkan kebutuhan revolusi industri, sesuai dengan kebutuhan kurikulum baru yang mampu membuka jendela dunia melalui genggaman, salah satu contohnya yaitu pemanfaatan "internet of things" (IOT), pada pendidikan terutama di Sekolah Menengah Kejuruan Pariwisata Aisyiyah.

Sekolah Menengah Kejuruan Pariwisata Aisyiyah (SMK) sekarang menerapkan Kurikulum 2013, UU No. 20 Tahun 2003. Kurikulum 2013 merupakan pembelajaran yang berpusat pada siswa, di mana siswa harus aktif dalam proses belajar-mengajar. Sementara itu peran guru hanya sebagai fasilitator, sehingga guru harus mempersiapkan media yang dapat membantu proses pembelajaran dan memberi ruang kepada siswa supaya bisa belajar secara mandiri dan memperoleh hasil yang maksimal (Mulyadi, 2015).

Media pembelajaran merupakan alat komunikasi guna lebih mengefektifkan proses belajar mengajar (Zubaidillah et al., 2016). Media pembelajaran juga salah satu komponen yang memiliki peranan penting saat pembelajaran. Pemanfaatan media harus menjadi perhatian guru dalam pembelajaran, maka guru sebagai fasilitator perlu mempelajari bagaimana menetapkan media pembelajaran yang efektif untuk mencapai tujuan pembelajaran.

Kegiatan pembelajaran di Sekolah Menengah Kejuruan Pariwisata Aisyiyah masih Konvensional (metode ceramah dan pemberian tugas). Menurut (Sugiyono, 2014), pembelajaran konvensional yaitu pembelajaran berpusat pada guru, namun kurang pemanfaatan media pembelajaran yang praktis dan efektif, serta belum mampu meningkatkan keaktifan siswa dalam pembelajaran. Guru disekolah ini masih terkendala dalam penggunaan media pembelajaran yang bisa meningkatkan keaktifan siswa, karena selama ini media yang diberikan guru belum menarik. Guru membutuhkan media pembelajaran yang mengikuti perkembangan teknologi saat sekarang. Salah satunya dengan penggunaan media Mobile Learning berbasis Moodle.

Mobile Learning sebagai sebuah inovasi dalam bidang pembelajaran memungkinkan proses pembelajaran menjadi lebih fleksibel tidak terpaku harus selalu di dalam kelas, laboratorium, dan berorientasi dominan kepada guru (teacher centered), melainkan pembelajaran memungkinkan untuk dilakukan secara mandiri oleh peserta didik (student centered) dengan menggunakan mobile yang dimiliki siswa (Surahman \& Surjono, 2017). 
Mobile Learning (M-Learning) juga merupakan proses belajar mengajar yang memanfaatkan teknologi berupa perangkat mobile, seperti Handphone, laptop, dan lain-lain, dimana pengguna bisa mengakses pembelajaran kapanpun dan di mana pun, tanpa harus terikat ruang dan waktu untuk memperoleh dan menggali ilmu pengetahuan. Dengan demikian penelitian ini bertujuan untuk melakukan uji praktikalitas dan efektifitas pengembangan media pembelajaran Mobile Learning berbasis Moodle pada mata pelajaran pengetahuan bahan makanan di sekolah menengah kejuruan pariwisata, karena selama ini media yang digunakan berbasis Moodle yaitu untuk perusahaan dan perkuliahan, serta untuk industri, sedangkan untuk pembelajaran disekolah masih minim, apa lagi di SMK pariwisata Aisyiyah tempat dilaksanakan penelitian. Maka dari itu untuk meningkatkan pengetahuan dan pembelajaran yang efektif diperlukan media yang interaktif yang mampu meningkatkan ke aktifan siswa.

\section{METODE PENELITIAN}

Jenis penelitian adalah Research and Development (R \& D) (Sugiyono, 2014), dengan model pengembangan adalah 4-D (four-D models), terdiri atas empat tahapan pengembangan yaitu (1) tahap pendefinisian (define) yakni tahap untuk menetapkan dan mendefinisikan syarat-syarat pembelajaran, (2) tahap perancangan (design) bertujuan untuk merancang perangkat pembelajaran, (3) tahap pengembangan (develop) bertujuan untuk menghasilkan produk pengembangan, melalui dua langkah yakni penilaian ahli dan pengguna, dan (4) tahap penyebaran (disseminate) (Trianto, 2014). Pengambilan data dilakukan dengan pemberian angket, dimana angket dirancang sesuai dengan kebutuhan dilapangan atau SMK tempat dilaksanakannya observasi. Berdasarkan hal tersebut disusun angket, selanjutnya diberikan kepada 3 praktisi ahli yaitu 2 guru SMK dari sekolah tempat penelitian dan 1 guru SMK dari sekolah lain, dan angket praktikalitas juga diberikan kepada pengguna yaitu 18 siswa yang dijadikan objek penelitian, sedangkan untuk efektifitas dilihat dari nilai pretest dan posttest siswa. Analisis data praktikalitas dengan statistik deskriptif (Riduwan., 2010) dan efektifitas dengan one grup pretest-posttest (Sugiyono, 2014). Lokasi penelitian itu yaitu SMK Pariwisata Aisyiyah Sumbar, siswa kelas X-Tata Boga yang mengambil mata pelajaran Pengetahuan Bahan Makanan.

\section{HASIL DAN PEMBAHASAN PENELITIAN}

Model pengembangannya yaitu Four-D, yang terdiri dari (1) Tahap pendefinisian (define) terdiri atas 3 langkah yaitu (a) Observasi Media, (b) Analisis Kurikulum, (c) Analisis Siswa, (2) Tahap perancangan (design) dimana dirancang angket, media dan bahan ajar, (3) Tahap pengembangan (develop) yaitu validitas yang terdiri atas 2 yaitu (1) validitas ahli media dengan hasil untuk aspek kebahasaan 0.92, aspek tampilan 0,92 dan aspek pemprograman 0,93 sehingga rata-rata $0,92,(2)$ validitas materi dengan nilai untuk aspek isi materi 0,88 , aspek pembelajaran 0,87 , aspek interaksi 0,88 dan aspek tampilan 0,86 , dengan rata-rata keseluruhan 0.87 (Santi, T. D., \& Faridah, 2021). Pada artikel ini akan dibahas tentang uji Praktikalitas dan Efektifitas dari media Mobile Learning berbasis Moodle yaitu sebagai berikut:

a. Uji Praktikalitas

Uji praktikalitas dilakukan pada guru dan siswa, karena guru yang akan menggunakan dan siswa yang memperoleh pembelajaran dengan menggunakan media pembelajaran Mobile Learning berbasis Moodle, untuk lebih jelasnya dapat dilihat pada gambar 1 berikut: 
2197 Praktikalitas dan Efektivitas Pengembangan Mobile Learning Berbasis Moodle pada Mata Pelajaran Pengetahuan Bahan Makanan di Sekolah Menengah Kejuruan - Anni Faridah, Titen Darlis Santi DOI: https://doi.org/10.31004/edukatif.v3i5.763

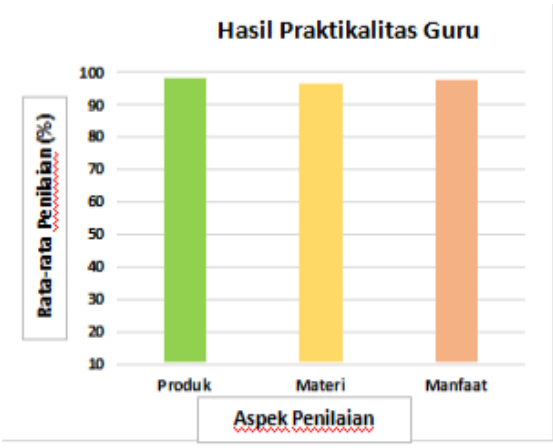

Gambar 1. Hasil Praktikalitas Guru

Berdasarkan gambar 1 dapat dijelaskan bahwa hasil praktikalitas guru, terhadap media mobile learning berbasis moodle pada mata pelajaran Pengetahuan Bahan Makanan dinyatakan "Sangat Praktis", dari 3 orang guru produktif. Tata Boga dimana rata-rata untuk aspek penilaian produk yaitu $97 \%$, aspek materi yaitu $96 \%$, dan aspek manfaat yaitu $95 \%$, sehingga diperoleh rata-rata untuk keseluruhan yaitu 95,6\%. Seiring dengan hal tersebut penelitian (Fransisca, 2017), menyatakan bahwa praktikalitas media E-Learning sangat praktis digunakan dalam proses pembelajaran di Sekolah Menengah Kejuruan, karena membantu siswa dalam memahami pembelajaran, dan siswa bisa aktif selama pembelajaran berlangsung. Sejana dengan itu hasil penelitian (Hignasari \& Supriadi, 2020) hasil dari pengisian angket penilaian terhadap media E-Learning dalam pembelajaran berada pada kategori tinggi, dimana respon mahasiswa terhadap e-learning dan implementasinya positif, dengan respon tersebut tentu meningkatkan minat dan motivasi belajar mahasiswa, sehingga media E-Learning sangat cocok diterapkan dalam pembelajaran pandemik sekarang.

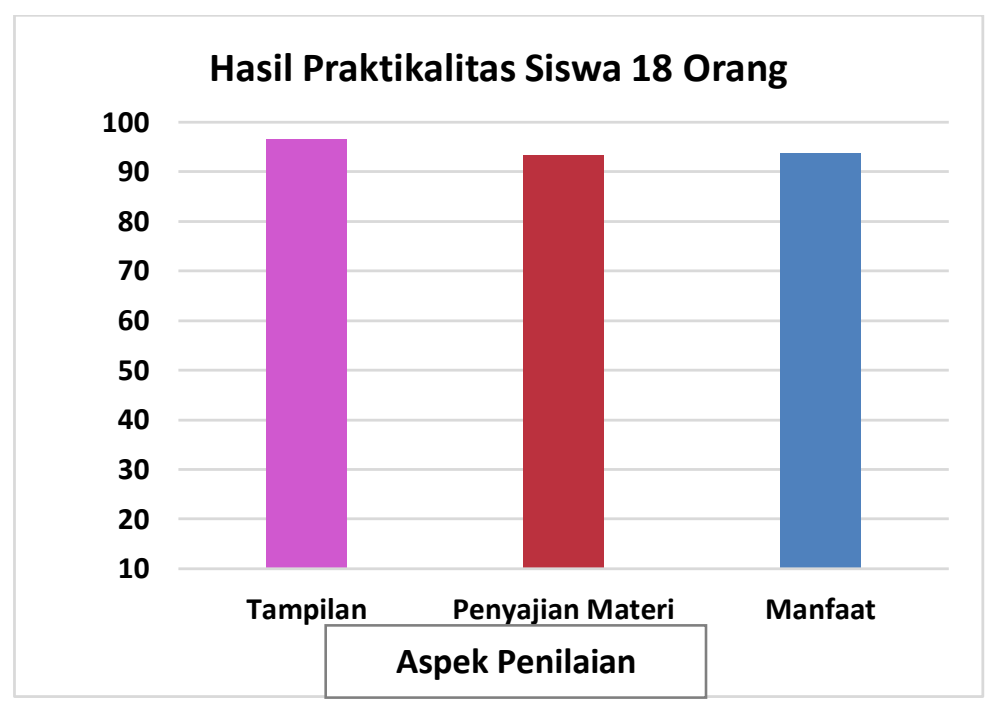

Gambar 2. Hasil Praktikalitas Siswa

Gambar 2 dapat dilihat bahwa hasil praktikalitas siswa, terhadap pengembangan media pembelajaran Mobile Learning berbasis Moodle pada mata pelajaran Pengetahuan Bahan Makanan dalam kategori "sangat praktis" dengan presentase nilainya 94,57\%, dari 18 orang siswa Tata Boga kelas X yang mengikuti pelajaran Pengetahuan Bahan Makanan, dengan kategori yang dinilai adalah tampilan 96,67\%, penyajian materi 93,33\% dan mafaat dari media yang diberikan $93,70 \%$. Seiring dengan hasil penelitian tersebut, menurut (Samala et al., 2019) nilai persentase praktikalitas berada pada rentang $80 \%-90 \%$, sehingga praktikalitas media secara keseluruhan dinyatakan "praktis" untuk digunakan guru dan peserta didik. Hasil penelitian (Maulana, 2021) menunjukkan bahwa pembelajaran daring solusi pandemi Covid-19 yang tidak hanya dapat diterapkan pada pendidikan tinggi, namun pendidikan vokasi yang mengutamakan keterampilan melalui mata kuliah praktik 
2198 Praktikalitas dan Efektivitas Pengembangan Mobile Learning Berbasis Moodle pada Mata Pelajaran Pengetahuan Bahan Makanan di Sekolah Menengah Kejuruan - Anni Faridah, Titen Darlis Santi

DOI: https://doi.org/10.31004/edukatif.v3i5.763

juga dapat melaksanakan perkuliahan daring, dimana hasil persepsinya berada pada kategori baik, antara penggunaan google classroom dari pada zoom meeting, apalagi menggunakan M-Learning.

b. Uji Efektifitas

Uji efektifitas diperoleh dari hasil belajar siswa, dimana hasil belajar tersebut merupakan aspek yang efektif untuk diamati dalam proses pembelajaran. Tujuan dari uji efektifitas ini untuk mengetahui sejauh mana efektifitas dari media yang dikembangkan, apakah membantu siswa dalam memahami materi pelajaran atau tidak. Uji efektifitas dilakukan setelah dilakukankan penerapan media pembelajaran yang dikembangkan berupa evaluasi dalam bentuk pretest dan posttest.

Hasil pretest yang dilakukan sebelum penerapan media, siswa yang "Tuntas" yaitu 6 siswa dari 18 siswa, selanjutnya diterapkan media Mobile Learning berbasis Moodle, selanjutnya diberikan Posttest dan hasilnya sangat memuaskan karena siswa yang "Tuntas" sebanyak 17 siswa dari 18 siswa dengan peningkatan presentasinya yaitu $85.56 \%$, berdasarkan hasil tersebut maka efektivitas penerapan media, media pembelajaran Pengetahuan Bahan Makanan sangat efektif. Seiring dengan hasil tersebut (Fransisca, 2017) Rata-rata dari nilai praktikalitas di atas menyatakan bahwa praktikalitas media E-Learning dikategorikan "Sangat Praktis" dengan nilai rata-rata $88,66 \%$ karena dengan persentase terebut sudah dapat dinilai bagaimana signifikannya hasil belajar yang diperoleh oleh siswa selama mempelajaran dengan menggunakan media E-Learning. Seiring dengan hasil tersebut berdasarkan hasil penelitian sebelumnya oleh (Sefriani \& Sepriana, 2020) bahwa media pembelajaran online menjadi alat bantu dalam proses pembelajaran sehingga memberikan dampak yang positif kepada yang menggunakannya, yang dapat meningkatkan hasil belajar siswa serta mengasah kemampuan literasi digital. Hasil penelitian (Hanum, 2013) hasil analisis keefektifan $e$ learning sebagai media pembelajaran di SMK berdasarkan standar mutu pelaksanaan e-learning dapat dinyatakan cukup efektif digunakan dalam proses pembelajaran. Berdasarkan hasil tersebut dapat disimpulkan bahwa media pembelajaran E-Learning mampu meningkatkan hasil belajar.

\section{KESIMPULAN}

Hasil analisis data terhadap media pembelajaran Mobile Learning berbasis Moodle sebagai media interaktif dari uji praktikalitas oleh Guru SMK dengan skor rata-rata 95,6\% dinyatakan "Sangat Praktis" dan untuk siswa diperoleh skor 94,57\% dinyatakan "Sangat Praktis". Kemudian untuk uji efektifitas diperoleh dari menganalisis nilai post-test 85,56\% dinyatakan tuntas dengan batas KKM 70, dimana dapat diartikan bahwa media pembelajaran Mobile Learning berbasis Moodle efektif untuk digunakan dalam pembelajaran Pengetahuan Bahan Makanan.

\section{DAFTAR PUSTAKA}

Fransisca, M. (2017). Pengujian Validitas, Praktikalitas, Dan Efektivitas Media E-Learning Di Sekolah Menengah Kejuruan. VOLT: Jurnal Ilmiah Pendidikan Teknik Elektro, 2(1), 17. Https://Doi.Org/10.30870/Volt.V2i1.1091

Hanum, N. S. (2013). Keefetifan E-Learning Sebagai Media Pembelajaran (Studi Evaluasi Model Pembelajaran E-Learning SMK Telkom Sandhy Putra Purwokerto). Jurnal Pendidikan Vokasi, 3(1), 90102. Https://Doi.Org/10.21831/Jpv.V3i1.1584

Hignasari, L. V., \& Supriadi, M. (2020). Pengembangan E-Learning Dengan Metode Self Assessment Untuk Meningkatkan Hasil Belajar Matematika Mahasiswa Universitas Mahendradatta. Jurnal Kependidikan: Jurnal Hasil Penelitian Dan Kajian Kepustakaan Di Bidang Pendidikan, Pengajaran Dan Pembelajaran, 6(2), 206. Https://Doi.Org/10.33394/Jk.V6i2.2476

Maulana, H. A. (2021). Persepsi Mahasiswa Terhadap Pembelajaran Daring Di Pendidikan Tinggi Vokasi: 
2199 Praktikalitas dan Efektivitas Pengembangan Mobile Learning Berbasis Moodle pada Mata Pelajaran Pengetahuan Bahan Makanan di Sekolah Menengah Kejuruan - Anni Faridah, Titen Darlis Santi DOI: https://doi.org/10.31004/edukatif.v3i5.763

Studi Perbandingan Antara Penggunaan Google Classroom Dan Zoom Meeting. Edukatif: Jurnal Ilmu Pendidikan, 3(1), 188-195. Https://Doi.Org/10.31004/Edukatif.V3i1.259

Mulyadi. (2015). Manajemen Sumber Daya Manusia (MSDM). In Manajemen Sumber Daya Manusia (MSDM). In Media.

Rahman, D. N. A., Saputra, D. S., \& Kurino, Y. D. (2019). Pemanfaatan Teknologi Mobile Learning Sebagai Media Pembelajaran Untuk Siswa Sekolah Dasar. In Prosiding Seminar Nasional Pendidikan, 1(Pp), 357-362.

Riduwan. (2010). Skala Pengukuran Variabel-Variabel Penelitian. In Skala Pengukuran Variabel-Variabel Penelitian. Alfabeta.

Rohida, L. (2018). Pengaruh Era Revolusi Industri 4.0 Terhadap Kompetensi Sumber Daya Manusia. Jurnal Manajemen Dan Bisnis Indonesia, 6(1), 114-136. Https://Doi.Org/10.31843/Jmbi.V6i1.187

Samala, A. D., Fajri, B. R., \& Ranuharja, F. (2019). Desain Dan Implementasi Media Pembelajaran Berbasis Mobile Learning Menggunakan Moodle Mobile App. Jurnal Teknologi Informasi Dan Pendidikan, 12(2), 13-19. Https://Doi.Org/10.24036/Tip.V12i2.221

Santi, T. D., \& Faridah, A. (2021). Cakrawala. Validitas Pengembangan Mobile Learning Berbasis Moodle Di Sekolah Menengah Kejuruan Pariwisata Aisyiyah Pada Mata Pelajaran Pengetahuan Bahan Makanan, 15(1), 20-28. Https://Doi.Org/10.24905/Cakrawala.V15i1.1800

Sefriani, R., \& Sepriana, R. (2020). Pengembangan Media E-Learning Berbasis Schoology Pada Pembelajaran Kurikulum Pendidikan Teknologi Dan Kejuruan. Edukasi: Jurnal Ilmu Pendidikan, 2017(1), 1-9.

Sugiyono. (2014). Metode Penelitian Pendidikan Pendekatan Kuantitatif, Kualitatif, Dan R\&Dno Title. In Metode Penelitian Pendidikan Pendekatan Kuantitatif, Kualitatif, Dan R\&D. Alfabeta.

Surahman, E., \& Surjono, H. D. (2017). Pengembangan Adaptive Mobile Learning Pada Mata Pelajaran Biologi SMA Sebagai Upaya Mendukung Proses Blended Learning. Jurnal Inovasi Teknologi Pendidikan, 4(1), 26. Https://Doi.Org/10.21831/Jitp.V4i1.9723

Trianto. (2014). Model Pembelajaran Terpadu: Konsep, Strategi, Dan Implementasinya Dalam Kurikulum Tingkat Satuan Pendidikan (KTSP). In Model Pembelajaran Terpadu: Konsep, Strategi, Dan Implementasinya Dalam Kurikulum Tingkat Satuan Pendidikan (KTSP). Bumi Aksara.

Zubaidillah, M. M., Kirana, T., \& Poedjiastoeti, S. (2016). Development Of STAD Cooperative Based Learning Set Assisted With Animation Media To Enhanche Students' Learning Outcome In MTS. Jurnal Pendidikan IPA Indonesia, 5(2), 247-255. Https://Doi.Org/10.15294/Jpii.V5i2.6004 